\title{
Effects of chronic vs. intermittent calorie restriction on mammary tumor incidence and serum adiponectin and leptin levels in MMTV-TGF- $\alpha$ mice at different ages
}

\author{
SONER DOGAN ${ }^{1}$, OLGA P. ROGOZINA ${ }^{1}$, ANNA E. LOKSHIN ${ }^{2}$, \\ JOSEPH P. GRANDE ${ }^{3}$ and MARGOT P. CLEARY ${ }^{1}$ \\ ${ }^{1}$ Hormel Institute, University of Minnesota, Austin, MN 55912; ${ }^{2}$ University of Pittsburgh Cancer Institute, \\ Hillman Cancer Centre Research Pavillion, Pittsburgh, PA 15213; ${ }^{3}$ Department of Pathology and \\ Laboratory Medicine, Mayo Foundation, Rochester, MN 55905, USA
}

Received January 28, 2009; Accepted July 31, 2009

DOI: 10.3892/ol_00000031

\begin{abstract}
Calorie restriction prevents mammary tumor (MT) development in rodents. Usually, chronic calorie restriction (CCR) has been implemented. In contrast, intermittent calorie restriction (ICR) has been less frequently used. Recent studies indicate that when a direct comparison of the same degree of CCR vs. ICR was made using MMTV-TGF- $\alpha$ mice which develop MTs in the second year of life, ICR provided greater protection than CCR in delaying MT detection and reducing tumor incidence. Adiponectin and leptin are two adipocytokines secreted from adipose tissue which have opposite effects on many physiological functions, including proliferation of human breast cancer cells. A recent study indicated that a low adiponectin/leptin ratio was associated with breast cancer. We evaluated the relationship of adiponectin and leptin to MT development in MMTV-TGF- $\alpha$ calorie-restricted mice at several ages. Mice were enrolled at 10 weeks of age and subjected to $25 \%$ caloric reduction implemented either chronically or intermittently. Mice were euthanized at designated time points up to 74 weeks of age. Serum samples were collected to measure adiponectin and leptin concentrations. Both CCR and ICR mice had significantly reduced MT incidence. For the groups studied, serum leptin increased over time, while there was a trend for an increase in serum adiponectin levels in ad libitum and ICR mice, with no change in CCR mice between 10 and 74 weeks of age. The adiponectin/leptin ratio
\end{abstract}

Correspondence to: Dr Margot P. Cleary, Hormel Institute, University of Minnesota, 801 16th Avenue NE, Austin, MN 55912, USA

E-mail: mpcleary@hi.umn.edu

Abbreviations: MT, mammary tumor; MFP, mammary fat pad; $\mathrm{AL}$, ad libitum; CCR, chronic calorie restriction; ICR, intermittent calorie restriction; $\mathrm{A} / \mathrm{L}$, adiponectin to leptin ratio

Key words: adiponectin, leptin, adiponectin/leptin ratio, mammary tumor, breast cancer, mouse, calorie restriction, energy restriction was significantly reduced as mice aged, but this ratio in ICR mice was significantly higher than that for ad libitum and CCR mice. No correlation was noted between serum adiponectin and leptin. These findings demonstrate that intermittent calorie restriction delays the early development of MTs. This delay was associated with reduced serum leptin levels following the restriction phases of the protocol. Additionally, serum leptin levels correlated with body weight and body fat in the groups studied.

\section{Introduction}

Breast cancer is a leading world-wide health problem, with millions of women succumbing to this disease each year. Animal studies have shown that calorie restriction is one of the most effective ways for the prevention of mammary tumor (MT) development, significantly decreasing both spontaneous and carcinogen-induced tumor incidence and tumor size (1-4). In this context, it has been reported that a $20-40 \%$ reduction in calorie intake resulted in significant decreases (up to 95\%) of MT incidence (4-8). Two major types of calorie restriction protocols have been applied in mammary tumorigenesis prevention: chronic calorie restriction (CCR) and intermittent calorie restriction (ICR), which refer to the application of periods of 'on' and 'off' caloric restriction. Although CCR has been studied extensively, ICR has been less well studied $(9,10)$. Additionally, in these studies direct comparisons of the two restriction methods (CCR vs. ICR) were not made.

We directly compared the roles of the two calorie restriction interventions on MT development in long-term longitudinal studies and found that ICR was more effective than CCR for MT prevention in two different transgenic mice strains, MMTV-TGF- $\alpha$ and MMTV-neu $(5,6,11)$. In particular, MMTV-TGF- $\alpha$ mice that were fed ad libitum had MT incidence in the range of $80 \%$, while the MT incidence rate was $\sim 4 \%$ in CCR mice which consumed $75 \%$ of the calories of ad libitum (AL) mice. However, MT incidence was only between 3 and $15 \%$ in ICR mice restricted to a similar overall degree, but in an intermittent fashion $(5,6)$. The protocol used was that ICR mice were provided with $50 \%$ of the caloric intake of the 
AL group during restriction periods, followed by ad libitum access to food during refeeding periods. On the other hand, CCR mice were provided daily with reduced amounts of food to equal the caloric and nutrient intake of ICR mice for each restriction/refeeding cycle.

Despite numerous studies describing the protective effect of calorie restriction, the exact mechanism(s) has yet to be determined. Nor is it clear whether the protection conferred by the two types of calorie restriction is mediated through the same mechanism. However, a number of circulating proteins such as IGF-I, IGFBPs, estrogen and insulin, have been studied extensively as possible mediators of the effect of calorie restriction (12-15). Recently, two other proteins, leptin and adiponectin, were also considered as growth factors for MTs (16-21). These two adipocytokines (adipokines) are secreted from adipose tissue and thus potentially provide a direct link of body weight/ body fat to mammary tumorigenesis. Breast cancer subjects have been reported to have lower adiponectin levels than unaffected controls, and in other studies leptin levels have been reported to be higher in breast cancer patients $(16,22-24)$. Of particular interest was a report that breast cancer subjects had a reduced serum adiponectin/leptin ratio compared to controls (16). With respect to leptin, when MMTV-TGF- $\alpha$ mice were cross-bred with either leptin-deficient or leptin receptor-deficient mice no MTs were detected $(25,26)$. Furthermore, in vitro studies indicated that while the addition of leptin stimulated human breast cancer cell proliferation, adiponectin inhibited it $(18,19,27,28)$. In vitro studies with breast and prostate cancer cell lines and preneoplastic colon cells further suggest that the ratio of adiponectin/leptin was important in cell proliferation (29-31).

Our study shows serum adiponectin and leptin levels and the adiponectin/leptin ratio obtained at specific time points between 10 and 74 weeks of age for MMTV-TGF- $\alpha$ female mice in relation to MT development. The ratio was obtained in association with two caloric restriction interventions, CCR and ICR. Additionally, we utilized controlled refeeding in this protocol because in previous studies mice in the ICR group sometimes consumed more food during the refeeding periods than AL-fed mice $(5,11)$. Thus, in the present study, food intake of the ICR mice during the refeeding periods was capped at $100 \%$ of what AL-fed mice consumed during the corresponding time period. Fat pad weights, serum leptin and adiponectin, as well as MT development were assessed. Correlations between the serum adipokines, as well as the correlation between body weight and serum adipokines in the MMTV-TGF- $\alpha$ mouse model were determined.

\section{Materials and methods}

Animals and study design. MMTV-TGF- $\alpha$ (C57/BL6) female mice, originally developed in the laboratory of Dr Robert J. Coffey, were used (32). These mice overexpress human TGF- $\alpha$, a part of an epidermal growth factor receptor (EGFR)/ErbB cascade which is known to play an important role in the development of human breast cancer (32-36).

The mice were obtained from a colony maintained at the Hormel Institute using the breeding protocol and genotyping assay previously described (6). At 10 weeks of age female MMTV-TGF- $\alpha$ mice were randomly assigned to three different experimental groups ad libitum, chronically calorie restricted (CCR) to $75 \%$ of AL-fed mice, or intermittent calorie restricted (ICR) implemented by 3 weeks of $50 \%$ restriction compared to the AL-fed group. This restriction was followed by 3 weeks of controlled refeeding ( $100 \%$ of the AL-fed group) resulting in $75 \%$ of caloric intake of AL-fed mice. Although the present study was similar to previous studies $(5,6)$, there are a few significant differences. In the current study, mice were euthanized at different time points. Mice in the ICR group were given only $100 \%$ of calories consumed by the AL-fed mice during refeeding periods, whereas in previous studies mice in the ICR groups had unlimited access to food during refeeding.

Diet composition. The mouse diets were purchased from Harlan Teklad (Madison, WI, USA). The diet compositions for each group were the same as those used in previous studies $(5,11,37)$. Briefly, mice in AL-fed groups were fed the AIN-93M diet $(5,11,37)$. Mice in the CCR group were fed a custom diet formulated to be isocaloric with the control diet with $25 \%$ increases in protein, vitamin, mineral and fat content $(38,39)$. This diet was given at $75 \%$ of age-matched ad libitum consumption. Mice assigned to the ICR group were provided with a 50\% restriction diet during each three-week restriction period with 2-fold increases in protein, vitamin, mineral and fat content. The restriction diet was isocaloric compared to the control diet. Following each restriction period, ICR mice were provided with the control diet at $100 \%$ of age-matched ad libitum consumption for three weeks. All mice had free access to water throughout the study. Diets were rendered isocaloric by adjustment of cellulose.

Mice were euthanized at designated ages: 10 (baseline), 13,$14 ; 25,26 ; 37,38 ; 55,56$ and 73,74 weeks of age. ICR mice were euthanized to correspond to the end of restriction periods at 13, 25, 37, 55 and 73 weeks of age and were further designated as ICR-restricted or ICR-refed following one week of refeeding at 14, 26, 38, 56 and 74 weeks of age. Since there were no differences in body weights of AL-fed and CCR mice for the one-week differences, the data were combined at each time point. Over the course of the experiment, weekly body weights and daily food consumptions were measured. At euthanasia, terminal blood samples were obtained from mice $5 \mathrm{~h}$ after introducing fresh food in the morning. Suspected MT or mammary tissue from the back of the neck, the location where MTs first form, was removed in addition to parametrial, retroperitoneal and mammary fat pad (MFP) tissues, and were weighed. A portion of these and any suspicious tissues were preserved in formalin and sent to the Department of Pathology and Laboratory Medicine, Mayo Foundation, Rochester, MN, for histopathological analyses to determine malignancy status in a blinded fashion. The remaining tissues were stored at $-80^{\circ} \mathrm{C}$ until used for future analyses. This study was approved by the University of Minnesota Institutional Animal Care and Use Committee in an AAALAC accredited facility.

Measurement of serum adiponectin and leptin levels. Blood samples were collected $5 \mathrm{~h}$ after the mice were given their daily allotment of food in the morning. Leptin levels were measured using the Mouse Adipokine LINCOplex Kit 96-Well Plate Assay, and adiponectin was measured using the Mouse Single Plex Adiponectin LINCOplex Kit 96-Well Plate Assay 
Table I. The effects of different modes of calorie restriction on the body weights, parametrial and retroperitoneal fat pad (Para and retro), mammary fat pad (MFP) and total fat (TF) weights at different ages in MMTV-TGF- $\alpha$ mice.

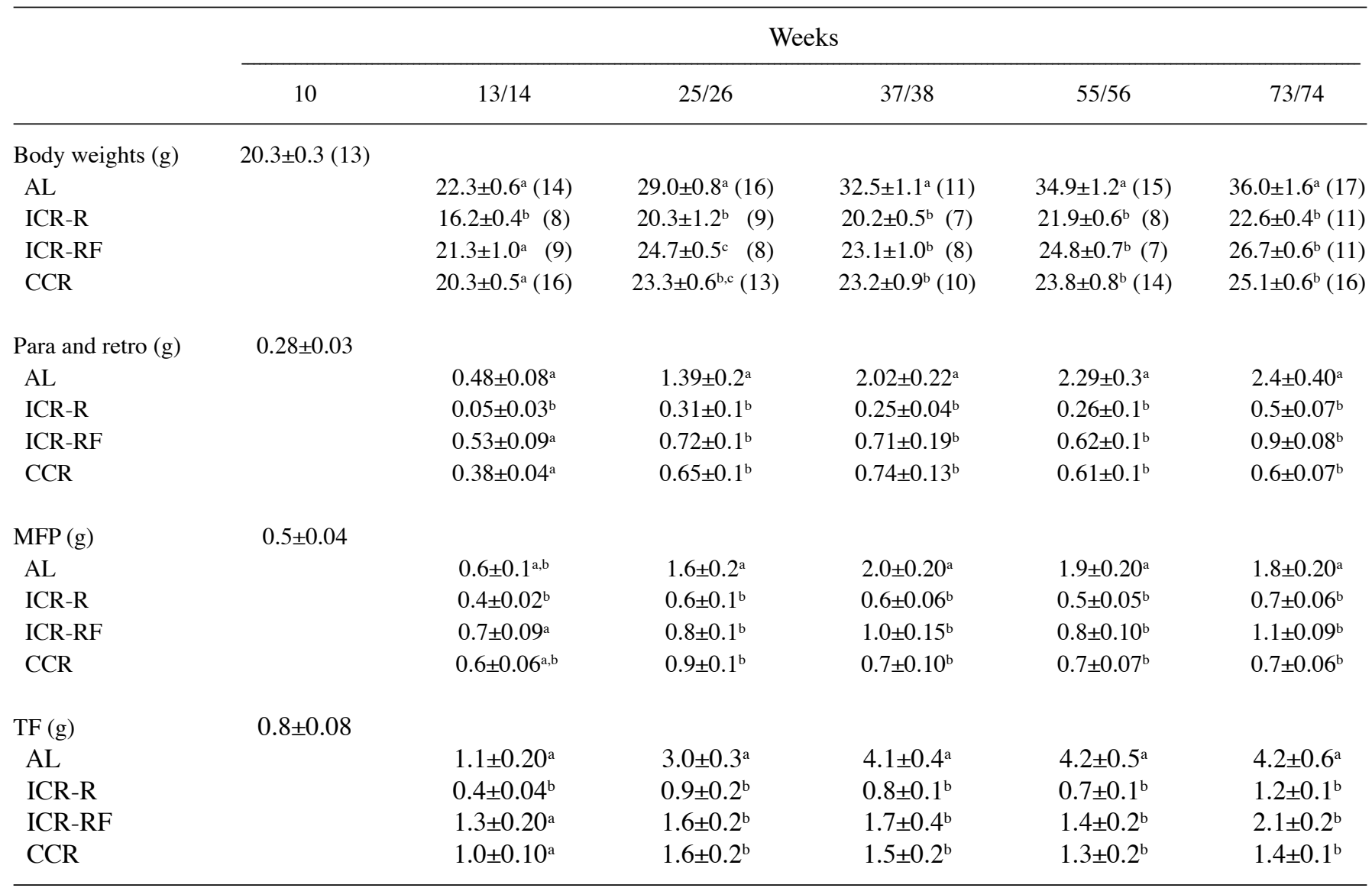

Values are presented as means \pm SEM. Numbers in parenthesis in body weights are ' $n$ ' values; ' $n$ ' values for para and retro, as well as MFP and TF are the same as ' $n$ ' values in body weights in the same age group. Values with different letters in the same column indicate a significant difference. AL, ad libitum; ICR-R, ICR-restricted; ICR-RF, ICR-refed and CCR, chronic calorie restriction.

(LINCO Research, St. Charles, MO, USA). Results were read on the Luminex 100 instrument. For the correlation and ratio metric analysis, the values from individual animals were used.

Statistical analysis. Results are presented as means \pm SEM. Tumor incidence data were analyzed by the Chi-square test. Comparisons among groups were made by ANOVA followed by Bonferroni's Multiple Comparison Test to determine whether the differences between specific groups were significant. The Spearman correlation test was used to determine whether the correlation between two parameters was statistically significant or not. As indicated above, since there is no significant difference between two consecutive time points at weeks 13 and 14, 25 and 26, 37 and 38, 55 and 56, and 73 and 74 for AL-fed and CCR mice, data from these two time points were combined. However, for ICR mice these time points were presented separately. Statistical significance was set at $\mathrm{P} \leq 0.05$.

\section{Results}

Body and fat pad weights (Table I). Body weights of ICRrestricted mice were significantly lower than those of the other groups at 13 weeks of age. There were no significant differ- ences for body weights among AL-fed, ICR-refed and CCR mice at week 13/14. At 25/26 weeks of age AL-fed mice had significantly higher body weight compared to the other groups and body weights of ICR-refed and CCR groups were similar. At the older ages of 37/38, 55/56 and 73/74 weeks, the AL-fed group had significantly higher body weight compared to the other groups, while there were no significant body weight differences among ICR-restricted, ICR-refed and CCR mice.

Changes in combined parametrial and retroperitoneal fat pad weights were similar to those observed for body weight. Mammary fat pad weights were also measured, and except at the first time point of 13/14 weeks of age, the two calorie restriction protocols resulted in significant reductions in mammary fat weight compared to AL-fed mice. Results at 13/14 weeks of age were statistically significant when comparing ICRrestricted and ICR-refed mice. When the fat pad weights were combined, AL-fed mice consistently had significantly higher values than the other three groups. There was a highly significant positive correlation between body weight and total fat pad weights in the three groups throughout the study ( $>0.77$, $\mathrm{P}<0.0001)$.

Effects of different modes of calorie restriction on MT incidence and latency (Fig. 1). In the present study, MTs were 

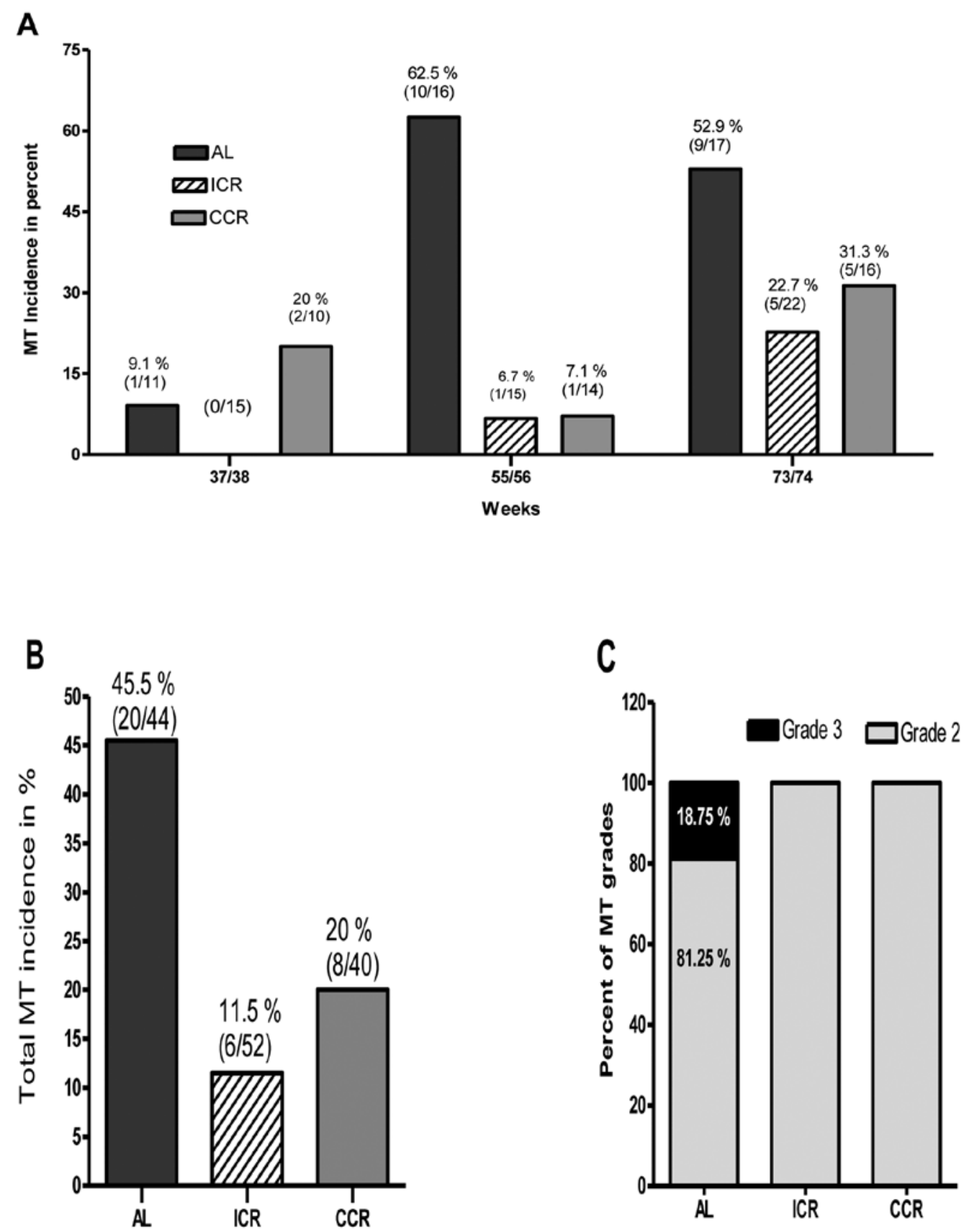

Figure 1. The effects of different modes of calorie restriction on mammary tumor development in MMTV-TGF- $\alpha$ mice euthanized at different ages. (A) Age of mammary tumor detection in ad libitum-fed (AL), intermittent calorie-restricted (ICR) and chronic calorie-restricted (CCR) mice with incidence rates. (B) Overall mammary tumor incidence for all mice. There were significant differences among the groups $(\mathrm{P}=0.0005)$. (C) Tumor grade for mammary tumors. The numbers in parenthesis are the number of mice that developed mammary tumors/total number of the mice.

detected by histopathological analysis because the design of the study was such that most mice were euthanized prior to when MTs would be able to be palpated. Mice were followed until their assigned endpoint, except when MTs were detected and reached $20 \mathrm{~mm}$ in diameter. No matter how MTs were initially detected, MT status was confirmed by histopathological analysis. For the calculation of MT incidence, mice euthanized either at or before week 26 were not included. Their exclusion occurred because the earliest age when MTs have been detected is $\sim 30$ weeks, both here and in previous studies $(5,6)$. In the present study, the earliest age at which MTs were detected was week 33, 37 and 56 for AL-fed, CCR and ICR groups, respectively. The MT incidence at specific ages is presented in Fig. 1A. Even though the presence of MT was obvious in one of the AL-fed mice at week 33, this mouse was euthanized at week $37 / 38$ and analyzed with the rest of the mice that were euthanized at week $37 / 38$. No statistically significant differences were noted among the groups for MT incidences at week $37 / 38(\mathrm{P}>0.05)$ when the three groups were analyzed together. However, the difference between CCR and ICR groups was significant when analyzed separately $(\mathrm{P}<0.05)$. MT incidence at week 55/56 was $62.5 \%(10 / 16)$ for the AL-fed group but was only $7.1 \%(1 / 14)$ and $6.7 \%$ (1/15) for CCR and ICR mice, respectively (AL-fed mice, and both CCR and ICR groups 
Table II. The effects of different modes of calorie restriction on the average of adiponectin, leptin and adiponectin/leptin ratio levels at different ages in MMTV-TGF- $\alpha$ mice.

\begin{tabular}{|c|c|c|c|c|c|c|}
\hline & \multicolumn{6}{|c|}{ Weeks } \\
\hline & 10 & $13 / 14$ & $25 / 26$ & $37 / 38$ & $55 / 56$ & $73 / 74$ \\
\hline $\begin{array}{l}\text { Adiponectin } \\
(\mu \mathrm{g} / \mathrm{ml})\end{array}$ & $14.4 \pm 1.3(32)$ & & & & & \\
\hline $\mathrm{AL}$ & & $13.1 \pm 1.0(33)$ & $17.4 \pm 1.4(30)$ & $19.8 \pm 1.3^{\mathrm{a}}(20)$ & $19.1 \pm 1.8(24)$ & $14.6 \pm 1.7^{\mathrm{a}}(15)$ \\
\hline ICR-R & & $16.1 \pm 1.8(17)$ & $16.6 \pm 2.2(13)$ & $25.9 \pm 3.7^{\mathrm{a}}(11)$ & $20.2 \pm 2.4(10)$ & $25.1 \pm 3.5^{\mathrm{b}}$ \\
\hline ICR-RF & & $13.8 \pm 1.5(14)$ & $17.7 \pm 2.4(11)$ & $21.2 \pm 2.6^{\mathrm{a}}(12)$ & $22.0 \pm 1.20(6)$ & $17.5 \pm 2.2^{\mathrm{a}, \mathrm{b}}(8)$ \\
\hline CCR & & $14.7 \pm 1.2(30)$ & $13.2 \pm 1.3(19)$ & $12.5 \pm 1.2^{\mathrm{b}}(20)$ & $14.0 \pm 1.1(22)$ & $14.7 \pm 1.2^{\mathrm{a}}(11)$ \\
\hline Leptin (ng/ml) & $0.3 \pm 0.04$ & & & & & \\
\hline $\mathrm{AL}$ & & $0.7 \pm 0.20$ & $3.5 \pm 0.6^{\mathrm{a}}(30)$ & $5.7 \pm 0.8^{\mathrm{a}}(21)$ & $6.1 \pm 0.7^{\mathrm{a}}(29)$ & $4.8 \pm 0.7(16)$ \\
\hline ICR-R & & $0.5 \pm 0.08$ & $1.5 \pm 0.3^{\mathrm{a}, \mathrm{b}}(16)$ & $2.3 \pm 0.5^{\mathrm{b}}(11)$ & $2.0 \pm 0.4^{\mathrm{b}}(12)$ & $2.6 \pm 0.4(9)$ \\
\hline ICR-RF & & $0.6 \pm 0.20$ & $0.9 \pm 0.3^{\mathrm{b}}(11)$ & $4.4 \pm 1.2^{\mathrm{a}, \mathrm{b}}(12)$ & $3.1 \pm 0.7^{\mathrm{a}, \mathrm{b}}(10)$ & $2.9 \pm 0.7(8)$ \\
\hline CCR & & $0.7 \pm 0.10$ & $2.6 \pm 0.4^{\mathrm{a}, \mathrm{b}}(20)$ & $3.2 \pm 0.4^{\mathrm{a}, \mathrm{b}}(20)$ & $3.7 \pm 0.5^{\mathrm{b}}(24)$ & $5.4 \pm 1.1(14)$ \\
\hline $\begin{array}{l}\text { Adiponectin/leptin } \\
(\mu \mathrm{g} / \mathrm{ml} \text { in 1000) }\end{array}$ & $113 \pm 23(32)$ & & & & & \\
\hline $\mathrm{AL}$ & & $59.4 \pm 10.8$ & $12.3 \pm 4.0^{\mathrm{a}}(30)$ & $5.2 \pm 0.9^{\mathrm{a}}(20)$ & $4.7 \pm 0.9^{\mathrm{a}}(24)$ & $4.4 \pm 0.7^{\mathrm{a}}(14)$ \\
\hline ICR-R & & $53.7 \pm 11.7(17)$ & $14.7 \pm 3.7^{\mathrm{a}}(13)$ & $18.5 \pm 5.0^{\mathrm{b}}(11)$ & $15.2 \pm 4.2^{\mathrm{b}}(10)$ & $15.5 \pm 5.6^{\mathrm{b}}$ \\
\hline ICR-RF & & $46.6 \pm 12.9(13)$ & $45.7 \pm 10^{\mathrm{b}}(11)$ & $7.8 \pm 1.4^{a}(12)$ & $18.4 \pm 6.0^{\mathrm{b}}(6)$ & $9.8 \pm 2.9^{\mathrm{a}, \mathrm{b}}(8)$ \\
\hline CCR & & $34.7 \pm 5.10(30)$ & $8.4 \pm 2.2^{\mathrm{a}}(19)$ & $4.5 \pm 0.4^{\mathrm{a}}(20)$ & $5.5 \pm 0.9^{\mathrm{a}}(22)$ & $3.8 \pm 0.8^{\mathrm{a}}(11)$ \\
\hline
\end{tabular}

Values are presented as means \pm SEM. Numbers in parenthesis are 'n' values; values in the same column with different letters indicate a significant difference. AL, ad libitum; ICR-R, ICR-restricted; ICR-RF, ICR-refed and CCR, chronic calorie restriction.

$\mathrm{P}=0.0009$ for $\mathrm{AL}-$ fed vs. CCR; $\mathrm{P}=0.0006$ for $\mathrm{AL}-$ fed vs. $\mathrm{ICR}$, and $\mathrm{P}>0.05$ for CCR vs. ICR). No statistically significant differences were noted among the three groups for MT incidences at week 73/74 $(\mathrm{P}>0.05)$ when the three groups were analyzed together. However, the difference between AL-fed and ICR groups was significant when analyzed directly $(\mathrm{P}<0.05)$. The overall MT incidences were $45.5 \%$ (20/44), 20\% (8/40) and $11.5 \%$ (6/52) for AL-fed, CCR and ICR groups, respectively, and differences among the groups were statistically significant $(\mathrm{P}=0.0005$; Fig. 1B). There was no significant difference between ICR and CCR groups $(\mathrm{P}>0.05)$ when the two groups were analyzed separately, despite the $100 \%$ lower incidence in ICR mice. This was at least partially attributable to the small number of mice in each group. Although all MTs were grade 2 for ICR and CCR mice, $18.75 \%$ (3/16) of the tumors for AL-fed mice were classified as grade 3 (high-grade) and the rest were grade 2 (Fig. 1C).

Effects of different modes of calorie restriction on serum adiponectin (Table II). Serum adiponectin concentrations were not affected by the different modes of calorie restriction at weeks 13/14, 25/26 and 55/56, but the serum adiponectin level of the CCR group was significantly lower than the other groups at week $37 / 38(\mathrm{P}<0.05)$. In addition, the ICR-restricted group had significantly higher serum adiponectin levels than that of either AL-fed $(\mathrm{P}<0.01)$ or CCR $(\mathrm{P}<0.05)$ mice at week $73 / 74$. Overall one week of refeeding after three weeks of restric- tion had no significant effects on serum adiponectin levels at any time points $(\mathrm{P}>0.05)$. Although age-related changes in serum adiponectin levels in the AL-fed and ICR groups were significant, there was no significant change for the CCR group. Serum adiponectin was not correlated with body weight in any groups at any age. There were no differences in serum adiponectin levels in mice which developed MT compared to mice that did not develop MT in any of the groups at any age.

Effects of different modes of calorie restriction on serum leptin (Table II). There were no significant differences in serum leptin levels among any dietary groups at week 13/14. However, the AL-fed group had a significantly higher serum leptin level than that of ICR-refed mice at week 25/26 and of ICR-restricted mice at week 37/38. At week 55/56, leptin in the AL-fed group was significantly higher than that of either ICR-restricted or ICR-refed mice. There were no significant differences among the groups for leptin at week $73 / 74$. Overall, serum leptin levels of ICR-restricted mice tended to be the lowest compared to AL-fed and CCR groups at each time point while values for the ICR-refed mice were consistently low to a lesser extent. The change in serum leptin levels for the AL-fed group over time was statistically significant $(\mathrm{P}<0.0001)$ as was the leptin/ body weight ratio $(\mathrm{P}<0.0001$; data not shown). This was primarily attributable to an early increase in serum levels between 13/14 and 25/26 weeks of age. Changes in serum leptin and leptin/body weight ratio in the CCR mice over the study were 


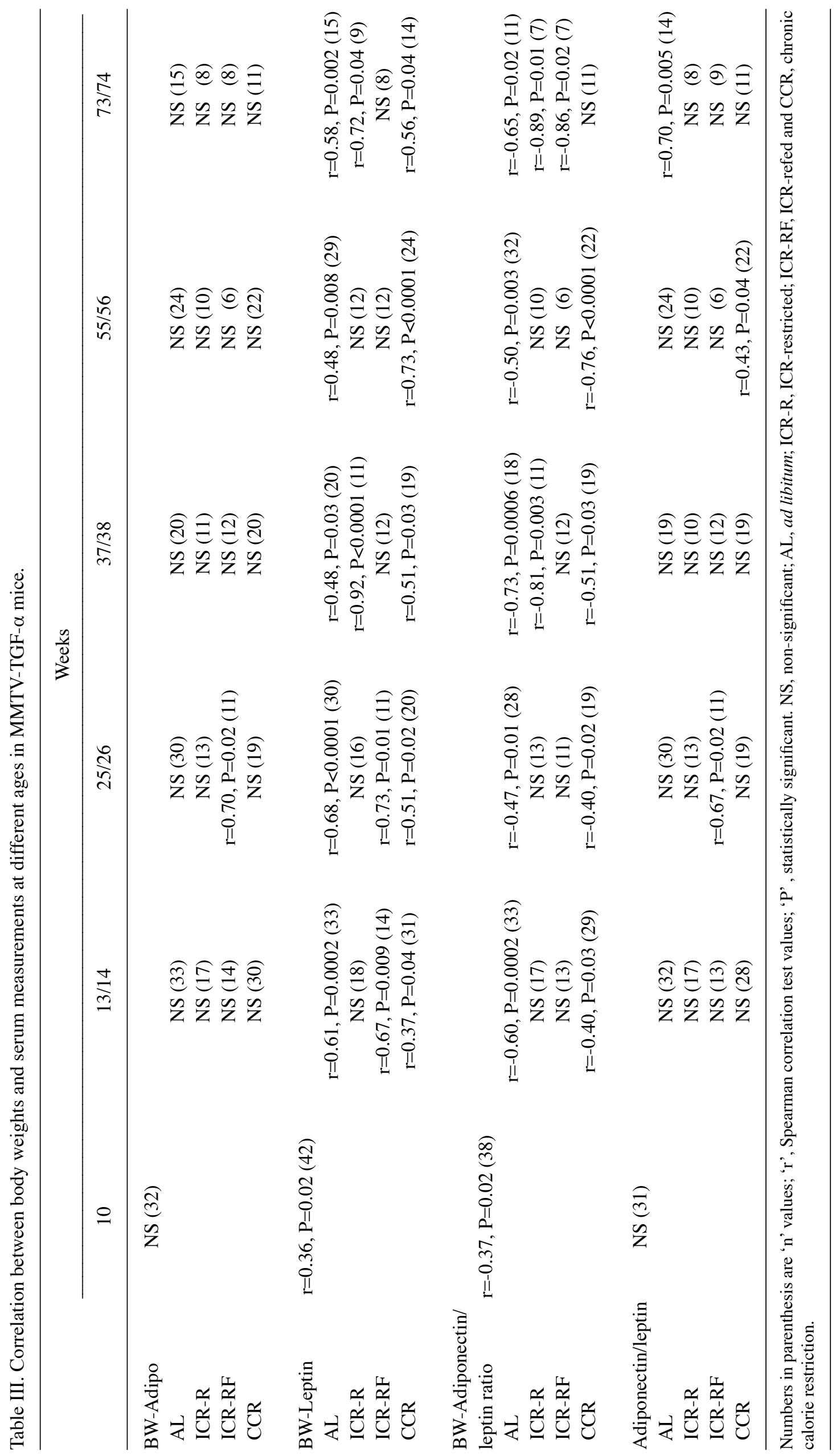


significant $(\mathrm{P}<0.0001)$. In the $\mathrm{CCR}$ group, the serum leptin level was gradually increased from week 10 until the end of the study at 73/74 weeks of age when it reached the maximum level at $5.4 \mathrm{ng} / \mathrm{ml}$ (Table II). Similar changes were observed in the leptin/body weight ratio for the AL-fed and CCR groups (data not shown). No significant differences were noted between ICR-restricted and ICR-refed mice for either serum leptin levels or leptin/body weight ratio levels at any given time point (Table II). Serum leptin levels in mice that developed MT compared to those mice that did not develop MT were similar within the AL and CCR groups at weeks 55/56 and 73/74 ( $\mathrm{P}>0.05$; data not shown).

Effects of different modes of calorie restriction on serum adiponectin to leptin ratio (Table II). No significant differences were noted among the groups for the adiponectin/ leptin ratio at week 13/14. ICR-refed mice had a significantly higher adiponectin/leptin ratio than the other groups at week 25/26, whereas the ICR-restricted group had a significantly higher adiponectin/leptin ratio than the other groups at week 37/38. Moreover, the ICR-restricted and ICR-refed groups had a significantly higher adiponectin/leptin ratio than either the AL-fed or CCR groups at week 55/56. At weeks 73/74 the ICR-restricted and ICR-refed groups had a higher adiponectin/ leptin ratio than either the AL-fed or CCR groups, although only the differences between ICR-refed and either AL-fed or CCR mice were significant. In general, there was an initial drop in the adiponectin/leptin ratio with age. Values were maintained for each group, but with the overall tendency for values to be higher for ICR mice. Changes in the adiponectin/ leptin ratio in the dietary groups over the study were statistically significant $(\mathrm{P}<0.0001)$. Serum adiponectin/leptin ratio levels (in $\mu \mathrm{g} / \mathrm{ml}$ ) in mice that developed MT vs. those that were tumor-free was similar within each dietary group at week 73/74 (in AL-fed group $4752 \pm 854$ vs. $3973 \pm 1035$; in ICR group $3195 \pm 762$ vs. $14843 \pm 3570$ and in CCR group $3490 \pm 1436$ vs. $2809 \pm 815$; $\mathrm{P}>0.05)$. In addition, serum adiponectin/leptin ratio levels in mice that developed $\mathrm{MT}$ and mice that did not develop MT were also similar at earlier time points $(\mathrm{P}>0.05$; data not shown).

Correlation between body weight and serum adiponectin, leptin and adiponectin to leptin ratio (Table III). There was a significantly positive correlation $(\mathrm{P}<0.001$, Spearman $\mathrm{r} \geq 0.77)$ between body weight and total fat in all of the groups studied (data not shown). Therefore, we present results for only one of these parameters, body weight, in association with serum measurements. No significant correlations were noted between body weight and serum adiponectin levels for any groups. In contrast, body weight and serum leptin levels were positively correlated at week 10 and at all time points for AL-fed and CCR mice. However, body weight and serum leptin were positively correlated only at weeks 37 and 73 for ICR-restricted mice and at weeks 14 and 26 for ICR-refed mice, although there was also a positive trend $(\mathrm{P}=0.08, \mathrm{r}=0.67)$ in the ICR-refed group at week 74 . There was a significant negative correlation between body weight and the serum adiponectin/leptin ratio for AL-fed mice at all time points. Similar results were observed for CCR mice except at week 73/74. However, the negative correlation was observed only at weeks 37 and 73 for
ICR-restricted mice and at week 74 for ICR-refed mice. There were few correlations of serum adiponectin and leptin levels in any of the experimental groups (Table III).

\section{Discussion}

A number of studies have reported that CCR significantly reduced MT incidence and delayed tumor latency in rodent models. Furthermore, our recent studies indicated that ICR provided a greater degree of prevention than CCR when applied to two different transgenic mice strains $(5,6,11)$. We confirm this finding in an analysis of one strain of transgenic mice, MMTV-TGF- $\alpha$, examined at different ages. The overall MT incidence rates were 45.5, 20 and $11.5 \%$ for AL-fed, CCR and ICR mice, respectively. We also show for the first time that in MMTV-TGF- $\alpha$ mice, MTs were histologically present at an earlier age than previously reported in longitudinal studies (Fig. 1A). Although MTs were detected as early as 33 and 37 weeks of age in AL-fed and CCR groups, the first MT was not detected in ICR mice until 55 weeks of age. In the present study, a histopathological analysis was used for MT detection as opposed to palpation. Fifty percent of the MTs in the AL-fed group developed either before or at week 55/56, while most of the MTs in ICR and CCR mice were not detected until week 73/74. In addition, calorie restriction significantly affected MT grade with higher grade MTs detected in AL-fed mice.

The present study is the first to report the effects of controlled caloric intake during refeeding periods on MT development in ICR mice. Interestingly, controlled refeeding had a similar effect to ad libitum refeeding on MT development, as the MT incidence of $10 \%$ was in the range of 3 and $15 \%$ previously reported for ICR mice that were allowed free access to food during refeeding in two earlier longitudinal studies $(5,6)$. Additionally, a recently completed longitudinal study using the controlled refeeding protocol resulted in an MT incidence rate of $9 \%$ for ICR mice compared to 71 and $35 \%$ for AL-fed and CCR mice (40). Integration of these findings suggest that the periods of severe restriction associated with the intermittent restriction protocol are important for the protective effect of ICR and that the refeeding aspect of the protocol does not influence the effect to any great degree.

Adiponectin and leptin have been reported to be important factors in the proliferation of human breast cancer cell lines (17-21,27,28). Additionally, measurement of serum levels of adiponectin and leptin have in some cases been reported to be associated with breast cancer, i.e., adiponectin levels in particular have been reduced and leptin increased (16,22-24). Notably, in one study adiponectin levels were reduced and leptin levels were elevated leading to a reduced adiponectin/ leptin ratio. We recently found that this ratio can modulate human breast cancer cell growth in vitro (29), while other studies have shown an impact of this ratio on pre-neoplastic colon and prostate cancer cells $(30,31)$. However, whether involvement of the serum adiponectin, leptin and especially adiponectin/leptin ratio is associated with MT prevention by calorie restriction remains unknown, but was investigated in the present study.

With respect to serum adiponectin, we found no consistent results associated with either calorie restriction protocol. However, some changes associated with age were noted, 
although these were not the same in all dietary groups. These observations are similar to previous animal and human studies. For example, it was reported that two months of $25 \%$ calorie restriction did not have any significant effects on the serum adiponectin level in CD-1 male mice (41). In another study, plasma adiponectin levels of male C57BL/6J mice were not affected by different levels of refeeding following alternate day calorie restriction at the end of four weeks (42). In additional studies, serum adiponectin levels were similar between fasted and fed mice (43) or high-fat and low-fat fed mice (44). On the other hand, six weeks of $30 \%$ calorie restriction of five-month-old wild-type C57BL/6J and transgenic male mice that overexpressed growth hormone, resulted in significant increases in serum adiponectin (45). In humans, the plasma adiponectin level was not changed by six months of fasting-induced weight loss in postmenopausal women (46), while in another study the adiponectin level was not affected by $48 \mathrm{~h}$ of fasting (47). Some human studies have reported that large weight loss or calorie restriction resulted in significantly increased serum adiponectin (48-51). In the present study, we observed that serum adiponectin levels were similar among the diet groups at weeks 10 and 74. However, changes in serum adiponectin levels were significant in AL-fed and ICR groups over the course of the study, while there was no significant change in the CCR group from 10 until 74 weeks of age.

Results for serum leptin indicated low initial levels with increases in all of the groups over time, although ICR mice appeared to have an age-related delay. Additionally, the ICR mice usually had reduced values, particularly after three weeks of caloric restriction compared to AL-fed and CCR mice which was probably attributable to body weight status. Interestingly, one week of refeeding did not have any significant effects on serum leptin. Most published studies report serum leptin and adiponectin values from either single or at most two time points $(41,42,45,46)$. Although in some studies calorie restriction significantly reduced serum leptin in humans and animals (46-48,52), calorie restriction did not have any significant effects on serum leptin levels in other studies $(41,45)$.

We also report on changes in the adiponectin/leptin ratio under normal physiological conditions (AL-fed group) and under the effects of different modes of calorie restriction. Overall, the adiponectin/leptin ratio drastically decreased from 10 until 74 weeks of age. Starting at week 25, the adiponectin/leptin ratio of ICR-restricted and ICR-refed mice was significantly higher than either AL-fed or CCR groups. These differences were greatest at weeks 55/56 and 73/74. These data indicate that one of the factors associated with lower MT incidence of ICR mice may be a higher serum adiponectin/ leptin ratio. As mentioned earlier, a recent study conducted with human subjects reported that the adiponectin/leptin ratio was reduced in women diagnosed with breast cancer compared to those without the disease (16). In addition, there was a significant negative correlation between the adiponectin/ leptin ratio and tumor size (16). The authors suggested that the serum adiponectin/leptin ratio may indicate the aggressiveness of breast cancer independent of BMI. We have also found higher adiponectin/leptin ratios to be associated with the delay in prostate cancer detection and death in the TRAMP mouse model as a result of the ICR protocol $(38,39)$. The adiponectin/ leptin ratio has also been investigated in a recent in vitro study where proliferation of estrogen receptor-positive and -negative breast cancer cells was significantly inhibited at a high adiponectin/leptin ratio, whereas, when the adiponectin/leptin ratio level was reduced there was an increased proliferation (53). These results suggest that individually adiponectin or leptin levels have no effect, but the balance of adiponectin to leptin may play important roles in cancer development. Another recent study reported that the adiponectin/leptin ratio was significantly lower in obese compared to lean mice, but there was no association with tumor growth resulting from implanted human breast cancer cells (54). In the present study, there were no consistent results for the adiponectin/leptin ratio for mice with and without MTs. This may be due to the small numbers of mice at each age and stage of disease. There is the possibility that mice that were tumor-free when they were euthanized would have eventually developed MTs if they had been followed for longer than 74 weeks of age as has been the case in longitudinal studies. Additionally, the genetic similarity of the mice may preclude serum factors from influencing mammary tumor development.

We determined correlations of serum leptin and adiponectin with each other as well as with other measurements. However, it was difficult to draw any general conclusions based on these results. Earlier studies have also reported conflicting results for the correlation between serum adiponectin and leptin levels. Although Gavrila et al reported no correlation between human serum adiponectin and leptin levels (47), a negative correlation between the two parameters was reported in another study (55). More interesting results were obtained for the correlation between body weight and serum parameters. Although the correlation between body weight and the serum adiponectin level was usually not significant, leptin was positively correlated with body weight but negatively correlated with the adiponectin/leptin ratio. There are also conflicting results for the correlation between body fat and serum adiponectin levels in previous studies (56-58). Our results support previous reports of a positive correlation between body weight and serum leptin in mice $(16,59-62)$.

In conclusion, we demonstrated the protective nature of ICR and CCR and found that ICR offers a greater prevention of MTs compared to an equal degree of calorie restriction implemented chronically (11.5 vs $20 \%$ total MT incidence and 18 weeks delay in MT development with ICR; Fig. 1A and B). We also demonstrated that the two modes of calorie restriction may have different effects on serum leptin levels as well as on the adiponectin/leptin ratio. Some of these effects may also be mediated by age. Although adiponectin and leptin have opposite effects on many physiological functions, there was no correlation between serum adiponectin and leptin levels in the present study. Finally, for the first time we reported that the adiponectin/leptin ratio significantly decreased from week 10-74 regardless of calorie intake. The adiponectin/ leptin ratio in ICR mice was significantly higher than that for CCR and AL-fed groups, especially after 26 weeks of age. Further studies will assess MT and mammary fat pad protein expression levels associated with these adipokines to further understand the mechanisms of action of the protective effect of ICR in the prevention of mammary tumorigenesis. 


\section{Acknowledgements}

This work was supported by grants CA101858 (M.P.C.), DK16105 (J.P.G.) and P30 CA47904-19 (A.E.L.), as well as by The Breast Cancer Research Foundation (M.P.C.) and The Hormel Foundation. The authors thank Rebecca N. LeVan for her technical assistance and Amy Snider, Laura Hamersma, Michelle Jacobson, Miranda Goff and Lynn Leraaen for animal care. The authors also thank Melissa J.L. Bonorden and Nancy K. Mizuno for maintaining the breeding colony and genotyping of the mice.

\section{References}

1. Dirx MJ, Zeegers MP, Dagnelie PC, Van den Bogaard T and Van den Brandt PA: Energy restriction and the risk of spontaneous mammary tumors in mice: a meta-analysis. Int $\mathrm{J}$ Cancer 106: 766-770, 2003.

2. Pariza MW: Fat, calories, and mammary carcinogenesis: net energy effects. Am J Clin Nutr 45: 261-263, 1987.

3. Tucker MJ: The effect of long-term food restriction on tumours in rodents. Int J Cancer 23: 803-807, 1979.

4. Gillette CA, Zhu Z, Westerlind KC, Melby CL, Wolfe P and Thompson HJ: Energy availability and mammary carcinogenesis: effects of calorie restriction and exercise. Carcinogenesis 18 : 1183-1188, 1997.

5. Cleary MP, Hu X, Grossmann ME, et al: Prevention of mammary tumorigenesis by intermittent caloric restriction: does caloric intake during refeeding modulate the response? Exp Biol Med 232: 70-80, 2007

6. Cleary MP, Jacobson MK, Phillips FC, Getzin SC, Grande JP and Maihle NJ: Weight-cycling decreases incidence and increases latency of mammary tumors to a greater extent than does chronic caloric restriction in mouse mammary tumor virus-transforming growth factor-alpha female mice. Cancer Epidemiol Biomarkers Prev 11: 836-843, 2002.

7. Thompson HJ, McGinley JN, Spoelstra NS, Jiang W, Zhu Z and Wolfe P: Effect of dietary energy restriction on vascular density during mammary carcinogenesis. Cancer Res 64: 5643-5650, 2004.

8. Zhu Z, Jiang W and Thompson HJ: An experimental paradigm for studying the cellular and molecular mechanisms of cancer inhibition by energy restriction. Mol Carcinog 35: 51-56, 2002.

9. Engelman RW, Day NK, Chen RF, et al: Calorie consumption level influences development of $\mathrm{C} 3 \mathrm{H} / \mathrm{Ou}$ breast adenocarcinoma with indifference to calorie source. Proc Soc Exp Biol Med 193: 23-30, 1990.

10. Carlson JA and Hoelzel F: Apparent prolongation of the life span of rats by intermittent fasting: one figure. J Nutr 31: 363-375, 1946.

11. Pape-Ansorge KA, Grande JP, Christensen TA, Maihle NJ and Cleary MP: Effect of moderate caloric restriction and/or weight cycling on mammary tumor incidence and latency in MMTV-Neu female mice. Nutr Cancer 44: 162-168, 2002.

12. Hankinson SE and Schernhammer ES: Insulin-like growth factor and breast cancer risk: evidence from observational studies. Breast Dis 17: 27-40, 2003.

13. Hartman J, Lindberg K, Morani A, Inzunza J, Strom A and Gustafsson JA: Estrogen receptor beta inhibits angiogenesis and growth of T47D breast cancer xenografts. Cancer Res 66 : 11207-11213, 2006.

14. Kaaks R: Nutrition, insulin, IGF-1 metabolism and cancer risk: a summary of epidemiological evidence. Novartis Found Symp 262: 247-260; discussion 260-268, 2004.

15. Lukanova A, Lundin E, Zeleniuch-Jacquotte A, et al: Body mass index, circulating levels of sex-steroid hormones, IGF-I and IGFbinding protein-3: a cross-sectional study in healthy women. Eur J Endocrinol 150: 161-171, 2004.

16. Chen DC, Chung YF, Yeh YT, et al: Serum adiponectin and leptin levels in Taiwanese breast cancer patients. Cancer letters 237: 109-114, 2006.

17. Nakayama S, Miyoshi Y, Ishihara H and Noguchi S: Growthinhibitory effect of adiponectin via adiponectin receptor 1 on human breast cancer cells through inhibition of S-phase entry without inducing apoptosis. Breast Cancer Res Treat 112: 405-410, 2008.
18. Hu X, Juneja SC, Maihle NJ and Cleary MP: Leptin-a growth factor in normal and malignant breast cells and for normal mammary gland development. J Natl Cancer Inst 94: 1704-1711, 2002.

19. Grossmann ME, Nkhata KJ, Mizuno NK, Ray A and Cleary MP: Effects of adiponectin on breast cancer cell growth and signaling. Br J Cancer 98: 370-379, 2008.

20. Ray A, Nkhata KJ and Cleary MP: Effects of leptin on human breast cancer cell lines in relationship to estrogen receptor and HER2 status. Int J Oncol 30: 1499-1509, 2007.

21. Vona-Davis L and Rose DP: Adipokines as endocrine, paracrine, and autocrine factors in breast cancer risk and progression. Endocr Relat Cancer 14: 189-206, 2007.

22. Korner A, Pazaitou-Panayiotou K, Kelesidis T, et al: Total and high-molecular-weight adiponectin in breast cancer: in vitro and in vivo studies. J Clin Endocrinol Metab 92: 1041-1048, 2007.

23. Miyoshi Y, Funahashi T, Kihara S, et al: Association of serum adiponectin levels with breast cancer risk. Clin Cancer Res 9: 5699-5704, 2003.

24. Tworoger SS, Eliassen AH, Kelesidis T, et al: Plasma adiponectin concentrations and risk of incident breast cancer. J Clin Endocrinol Metab 92: 1510-1516, 2007.

25. Cleary MP, Juneja SC, Phillips FC, Hu X, Grande JP and Maihle NJ: Leptin receptor-deficient MMTV-TGF-alpha/ Lepr $(\mathrm{db}) \operatorname{Lepr}(\mathrm{db})$ female mice do not develop oncogene-induced mammary tumors. Exp Biol Med 229: 182-193, 2004.

26. Cleary MP, Phillips FC, Getzin SC, et al: Genetically obese MMTV-TGF-alpha/Lep(ob)Lep(ob) female mice do not develop mammary tumors. Breast Cancer Res Treat 77: 205-215, 2003.

27. Dieudonne MN, Bussiere M, Dos Santos E, Leneveu MC, Giudicelli Y and Pecquery R: Adiponectin mediates antiproliferative and apoptotic responses in human MCF7 breast cancer cells. Biochem Biophys Res Commun 345: 271-279, 2006.

28. Dieudonne MN, Machinal-Quelin F, Serazin-Leroy V, Leneveu MC, Pecquery R and Giudicelli Y: Leptin mediates a proliferative response in human MCF7 breast cancer cells. Biochem Biophys Res Commun 293: 622-628, 2002.

29. Grossmann EM, Ray A, Dogan S, Mizuno KN and Cleary MP: Balance of adiponectin and leptin in relationship to breast cancer cell growth. Cell Research (In press).

30. Mistry T, Digby JE, Desai KM and Randeva HS: Leptin and adiponectin interact in the regulation of prostate cancer cell growth via modulation of $\mathrm{p} 53$ and bcl-2 expression. BJU Int 101: 1317-1322, 2008

31. Fenton JI, Birmingham JM, Hursting SD and Hord NG: Adiponectin blocks multiple signaling cascades associated with leptin-induced cell proliferation in Apc Min/+ colon epithelial cells. Int J Cancer 122: 2437-2445, 2008.

32. Matsui Y, Halter SA, Holt JT, Hogan BL and Coffey RJ: Development of mammary hyperplasia and neoplasia in MMTV-TGF alpha transgenic mice. Cell 61: 1147-1155, 1990.

33. Lundy J, Schuss A, Stanick D, McCormack ES, Kramer S and Sorvillo JM: Expression of neu protein, epidermal growth factor receptor and transforming growth factor alpha in breast cancer. Correlation with clinicopathologic parameters. Am J Pathol 138: 1527-1534, 1991.

34. Murray PA, Barrett-Lee P, Travers M, Luqmani Y, Powles T and Coombes RC: The prognostic significance of transforming growth factors in human breast cancer. Br J Cancer 67: 1408-1412, 1993.

35. Rajkumar T and Gullick WJ: The type I growth factor receptors in human breast cancer. Breast Cancer Res Treat 29: 3-9, 1994.

36. Panico L, D'Antonio A, Salvatore G, et al: Differential immunohistochemical detection of transforming growth factor alpha, amphiregulin and CRIPTO in human normal and malignant breast tissues. Int J Cancer 65: 51-56, 1996.

37. Reeves PG, Nielsen FH and Fahey GC Jr: AIN-93 purified diets for laboratory rodents: final report of the American Institute of Nutrition ad hoc writing committee on the reformulation of the AIN-76A rodent diet. J Nutr 123: 1939-1951, 1993.

38. Bonorden MJL, Rogozina OP, Kluczny CM, Grossmann ME, Grambsch PL, Grande JP, Perkins SN, Lokshin A and Cleary MP: Intermittent calorie restriction delays prostate tumor detection and increases survival time in TRAMP mice. Nutr Cancer 61: 265-275, 2009.

39. Bonorden MJL, Rogozina OP, Kluczny CM, Grossmann ME, Grande JP, Loshkin A and Cleary MP: Cross-sectional analysis of intermittent versus chronic caloric restriction in the TRAMP mouse. Prostate 69: 317-326, 2009. 
40. Rogozina OP, Bonorden MJL, Grande JP and Cleary MP: Serum insulin like growth factor-I and mammary tumor development in ad libitum-fed, chronic calorie-restricted and intermittent calorierestricted MMTV-TGF- $\alpha$ mice. Cancer Prev Res 2: 712-719, 2009.

41. Silha JV, Weiler HA and Murphy LJ: Plasma adipokines and body composition in response to modest dietary manipulations in the mouse. Obesity 14: 1320-1329, 2006.

42. Varady KA, Roohk DJ, Loe YC, McEvoy-Hein BK and Hellerstein MK: Effects of modified alternate-day fasting regimens on adipocyte size, triglyceride metabolism, and plasma adiponectin levels in mice. J Lipid Res 48: 2212-2219, 2007.

43. Bluher M, Fasshauer M, Kralisch S, Schon MR, Krohn K and Paschke R: Regulation of adiponectin receptor R1 and R2 gene expression in adipocytes of C57BL/6 mice. Biochem Biophys Res Commun 329: 1127-1132, 2005.

44. Barnea M, Shamay A, Stark AH and Madar Z: A high-fat diet has a tissue-specific effect on adiponectin and related enzyme expression. Obesity 14: 2145-2153, 2006.

45. Wang Z, Masternak MM, Al-Regaiey KA and Bartke A: Adipocytokines and the regulation of lipid metabolism in growth hormone transgenic and calorie-restricted mice. Endocrinology 148: 2845-2853, 2007.

46. Ryan AS, Nicklas BJ, Berman DM and Elahi D: Adiponectin levels do not change with moderate dietary induced weight loss and exercise in obese postmenopausal women. Int J Obes Relat Metab Disord 27: 1066-1071, 2003.

47. Gavrila A, Chan JL, Yiannakouris N, et al: Serum adiponectin levels are inversely associated with overall and central fat distribution but are not directly regulated by acute fasting or leptin administration in humans: cross-sectional and interventional studies. J Clin Endocrinol Metab 88: 4823-4831, 2003.

48. Hotta K, Funahashi T, Arita Y, et al: Plasma concentrations of a novel, adipose-specific protein, adiponectin in type 2 diabetic patients. Arterioscler Thromb Vasc Biol 20: 1595-1599, 2000.

49. Hulver MW, Zheng D, Tanner CJ, et al: Adiponectin is not altered with exercise training despite enhanced insulin action. Am J Physiol Endocrinol Metab 283: E861-E865, 2002.

50. Yang WS, Lee WJ, Funahashi T, et al: Weight reduction increases plasma levels of an adipose-derived anti-inflammatory protein, adiponectin. J Clin Endocrinol Metab 86: 3815-3819, 2001.

51. Weiss EP, Racette SB, Villareal DT, et al: Improvements in glucose tolerance and insulin action induced by increasing energy expenditure or decreasing energy intake: a randomized controlled trial. Am J Clin Nutr 84: 1033-1042, 2006.
52. Zhang Y, Matheny M, Zolotukhin S, Tumer N and Scarpace PJ: Regulation of adiponectin and leptin gene expression in white and brown adipose tissues: influence of beta3-adrenergic agonists, retinoic acid, leptin and fasting. Biochim Biophys Acta 1584: 115-122, 2002.

53. Grossmann ME, Ray A, Dogan S, Mizuno NK and Cleary MP: Balance of adiponectin and leptin in relationship to breast cancer cell growth. Cell Res 18: 1154-1156, 2008.

54. Nkhata KJ, Ray A, Dogan S, Grande JP and Cleary MP: Mammary tumor development from T47-D human breast cancer cells in obese ovariectomized mice with and without estradiol supplements. Breast Cancer Res Treat 114: 71-83, 2009.

55. Matsubara M, Maruoka S and Katayose S: Inverse relationship between plasma adiponectin and leptin concentrations in normal-weight and obese women. Eur J Endocrinol 147: 173-180, 2002.

56. Cnop M, Havel PJ, Utzschneider KM, et al: Relationship of adiponectin to body fat distribution, insulin sensitivity and plasma lipoproteins: evidence for independent roles of age and sex. Diabetologia 46: 459-469, 2003.

57. Vendrell J, Broch M, Vilarrasa N, et al: Resistin, adiponectin, ghrelin, leptin, and proinflammatory cytokines: relationships in obesity. Obes Res 12: 962-971, 2004.

58. Anderlova K, Kremen J, Dolezalova R, et al: The influence of very-low-calorie-diet on serum leptin, soluble leptin receptor, adiponectin and resistin levels in obese women. Physiol Res 55: 277-283, 2006.

59. Cleary MP, Grande JP, Juneja SC and Maihle NJ: Diet-induced obesity and mammary tumor development in MMTV-neu female mice. Nutr Cancer 50: 174-180, 2004.

60. Ray A, Nkhata KJ, Grande JP and Cleary MP: Diet-induced obesity and mammary tumor development in relation to estrogen receptor status. Cancer Lett 253: 291-300, 2007.

61. Dogan S, Hu X, Zhang Y, Maihle NJ, Grande JP and Cleary MP: Effects of high fat diet and/or body weight on mammary tumor leptin and apoptosis signaling pathways in MMTV-TGF-alpha mice. Breast Cancer Res 9: R91, 2007.

62. Ostlund RE Jr, Yang JW, Klein S and Gingerich R: Relation between plasma leptin concentration and body fat, gender, diet, age and metabolic covariates. J Clin Endocrinol Metab 81: 3909-3913, 1996 